\title{
Código de ética y buenas prácticas editoriales
}

La Universidad EAN propende por estimular las buenas prácticas editoriales desde la perspectiva de la Institución, los autores y los lectores. Igualmente, vela por el respeto al derecho de autor, propio y ajeno. En este sentido, los autores deben garantizar que los datos y resultados presentados son originales, tienen la potestad para su divulgación, no han sido copiados, manipulados o distorsionados.

En concordancia con los lineamientos del Comité de Ética en la Publicación (COPE), y teniendo como referentes su Código de conducta y mejores prácticas para editores (2011), su Código de directrices éticas para pares revisores (2013) y su Guía de estándares internacionales para autores (2010), la Revista Escuela de Administración de Negocios formula las siguientes directrices de buenas prácticas:

\section{Para la Editorial}

- Proteger la propiedad intelectual y derechos de autor.

- Mantener independencia editorial.

- Mantener su compromiso con el mejoramiento continuo de la revista.

- Cuidar la integridad de la producción científica que se publica en la revista.

- Publicar correcciones, aclaraciones, retractaciones y disculpas, en los casos en que sea necesario y con la debida oportunidad.

- Velar porque el proceso de editorial sea riguroso y transparente.

- Cumplir la decisión de aceptación o rechazo de un artículo para su publicación.

- Explicitar las condiciones de acceso a la revista y de las posibilidades de uso de los diferentes artículos en el marco del derecho de autor.

- Establecer relaciones cordiales, basadas en el eje del respeto, con todos los actores involucrados en el proceso editorial.

- Resolver de forma oportuna y suficiente las inquietudes que presenten los actores involucrados en el proceso editorial, respecto a este.

\section{Para los autores}

- Garantizar la originalidad del contenido que se presenta en el artículo.

- Garantizar que el documento que se somete a consideración para publicación es inédito.

- Respetar el derecho de autor. No llevar a cabo prácticas de plagio o autoplagio.

- Suministrar la información completa y correcta sobre las referencias bibliográficas y fuentes de información — de información, figuras y tablas — que se utilizan en el artículo.

- Obtener y suministrar las autorizaciones que se requieran de las personas o entidades involucradas en la investigación, en sus datos, fotografías, etc.

- Respetar el orden de la autoría aceptado por el grupo de autores. 
- Hacer explícito en el artículo las consideraciones éticas que se tuvieron en cuenta en la investigación, cuando esta así lo requiera.

- Asumir la responsabilidad de sus propios planteamientos y de la información que presenta.

- Realizar, en el plazo establecido, los ajustes que el texto requiera, dentro del proceso editorial.

- Respetar la confidencialidad sobre personas y organizaciones cuando así se ha acordado.

- Suministrar los datos requeridos por la revista, a través del «Formato de autorización para publicación», con el fin de llevar a cabo de forma efectiva el registro de autores en Publindex y demás bases de datos en los que sea requerido.

- Establecer relaciones cordiales, basadas en el eje del respeto, con todos los actores involucrados en el proceso editorial.

\section{Para los pares evaluadores}

- Comunicar al editor cuando exista conflicto de intereses.

- Cumplir los plazos establecidos para el proceso de evaluación.

- Realizar una evaluación seria y fundamentada en el rigor científico, originalidad y pertinencia de la información.

- Seguir el protocolo de evaluación entregado por la revista.

- Realizar de forma respetuosa y constructiva los comentarios que surjan a raíz de la evaluación del artículo.

- Llevar a cabo el proceso de verificación de ajustes, solicitados en la evaluación inicial.

- Mantener la confidencialidad del proceso de evaluación que realice.

- Suministrar los datos requeridos por la revista, a través del «Formato de evaluación de artículos», con el fin de llevar a cabo de forma efectiva el registro de evaluadores en Publindex y demás bases de datos en los que sea requerido.

- Establecer relaciones cordiales, basadas en el eje del respeto, con todos los actores involucrados en el proceso editorial.

\section{Para los lectores}

Hacer uso de la información de acuerdo con lo establecido en licencia de Creative Commons ReconocimientoNoComercial-SinObraDerivada 4.0 Internacional.

\section{Sobre plagio y autoplagio}

Se considera plagio la copia textual o parcial de ideas ajenas que se presentan como propias. Por lo tanto, se entiende como apropiación intelectual indebida.

Por lo anterior, cada autor, en sus escritos, debe respetar el derecho que surge sobre ideas, criterios, figuras, tablas, y en general, todo tipo de obras que se tomen de otros autores; es decir, debe darles su respectivo crédito.

En cuanto al autoplagio, se trata de las publicaciones anteriores elaboradas por autores, que, a su vez, consideran que pueden utilizar información de estos materiales sin indicar que, primero, ya fueron publicados, y segundo, 
que es de su autoría. Esta práctica, desde cualquier punto de vista ético, es inapropiado y rechazado en el marco de la escritura científica.

Los artículos que incurran en cualquiera de estas dos situaciones -plagio o autoplagio-, no serán considerados, bajo ninguna circunstancia, para surtir el proceso de publicación en la revista. Dado el caso se realizará la respectiva notificación de rechazo, haciendo explícito el motivo.

La Revista Escuela de Administración de Negocios utiliza el software Safe Assign para la verificación de plagio y autoplagio en sus artículos.

\section{Code of ethics and good editorial practices}

The Universidad EAN promotes good editorial practices from the perspective of the Institution, the authors, and the readers. Likewise, it ensures respect for copyright, own and that of others. In this sense, the authors must guarantee that the data and results that they are presenting are original, have the power for their disclosure, and have not been copied, manipulated, or distorted.

In accordance with the guidelines of the Committee on Ethics in Publication (COPE), and taking as references their Código de conducta y mejores prácticas para editores (2011), their Código de directrices éticas para pares revisores (2013), and their Guía de estándares internacionales para autores (2010), the Escuela de Administración de Negocios Journal formulates the following guidelines of good practice:

\section{For the Editorial}

- Protect intellectual property and copyright.

- Maintain editorial independence

- Maintain the commitment to the continuous improvement of the journal.

- Take care of the integrity of the scientific production that is published in the journal.

- Publish corrections, clarifications, retractions, and apologies when necessary and with due opportunity.

- Ensure that the editorial process is rigorous and transparent.

- Fulfill the decision of acceptance or rejection of an article for publication.

- Explain the conditions to access the journal and the possibilities of using the different articles within the framework of copyright.

- Establish cordial relationships, based on the axis of respect, with all the actors who are involved in the editorial process.

- Solve in a timely and sufficient manner the concerns that are presented by the actors who are involved in the editorial process, regarding the editorial process. 


\section{For the authors}

- Guarantee the originality of the content that is presented in the article.

- Ensure that the document that was submitted to be considered for publication is unpublished.

- Respect copyright. Do not carry out practices of plagiarism or self-plagiarism.

- Provide complete and correct information about bibliographic references and sources of information - of information, figures, and tables - that are used in the article.

- Obtain and supply the authorizations that are required from the persons or entities that are involved in the investigation, in their data, photographs, etc.

- Respect the order of authorship accepted by the group of authors.

- Within the article, specify the ethical considerations that were taken into account in the investigation, when required.

- Take the responsibility for own approaches and information that is presented.

- Carry out the adjustments that the text requires within the editorial process, in the time that has been established.

- Respect the confidentiality of people and organizations when it has been agreed that way.

- Provide the data that is required by the journal, through the "Authorization for Publication Form", in order to effectively carry out the registration of authors in Publindex and other databases in which it is required.

- Establish cordial relationships, based on the axis of respect, with all the actors involved in the editorial process.

\section{For peer reviewers}

- Communicate to the editor when there is a conflict of interest.

- Fulfill the deadlines that are established for the evaluation process.

- Carry out a serious evaluation based on the scientific rigor, originality, and relevance of the information.

- Follow the evaluation protocol that is delivered by the journal.

- Present the comments that arise as a result of the evaluation of the article in a respectful and constructive manner.

- Carry out the process of verification of adjustments, requested in the initial evaluation.

- Maintain the confidentiality of the evaluation process that is performed.

- Provide the data that is required by the journal, through the «article evaluation format», in order to carry out an effective registration of evaluators in Publindex and other databases in which it is required.

- Establish cordial relationships, based on the axis of respect, with all the actors involved in the editorial process.

\section{For readers}

- Make use of the information in accordance with what is established in the Creative Commons AttributionNonCommercial-NoDerivative 4.0 International license. 


\section{About plagiarism and self-plagiarism}

Plagiarism is the textual or partial copy of ideas from others that are presented as own. Therefore, it is understood as undue intellectual appropriation.

Therefore, authors must respect the right that arises on ideas, criteria, figures, tables, and in general, all kinds of works that are taken from other authors in their writings; that is, it is a must to give respective credit to writings carried out by other authors.

As for self-plagiarism, it has to do with the publications that have been previously prepared by authors, who in turn, consider that they can use information from these materials without indicating that they have already been published and that the document is their authorship. This practice, from any ethical point of view, is inappropriate and rejected in the framework of scientific writing.

The articles that incur in any of these two situations - plagiarism and self-plagiarism - will not be considered, under any circumstance, to fill the process of publication in the journal. Given the case, the rejection notice will be made, explaining specifically the reason for that rejection.

The School of Business Administration Journal uses the software Safe Assign for the verification of plagiarism and self-plagiarism in its articles.

\section{Código de ética e boas práticas editoriais}

A Universidade EAN estimula as boas práticas editoriais a partir da perspectiva da Instituição, dos autores e dos leitores. Igualmente, vela pelo respeito ao direito de autor, próprio e alheio. Neste sentido, os autores devem garantir que os dados e resultados apresentados sejam originais, que têm a potestade para sua divulgação, não foram copiados, manipulados ou distorcidos.

De acordo com as linhas do Comitê de Ética na Publicação (COPE), e tendo como referentes seu Código de conduta e melhores práticas para editores (2011), seu Código de diretrizes éticas para pare revisores (2013) e seu Guia de regulares internacionais para autores (2010), a Revista Escuela de Administración de Negocios formula as seguintes diretrizes de boas práticas:

\section{Para a Editora}

- Proteger a propriedade intelectual e direitos de autor.

- Manter independência editorial.

- Manter seu compromisso com a melhora contínua da revista.

- Cuidar da integridade da produção científica que se publica na revista.

- Publicar correções, esclarecimentos, retratações e desculpas, nos casos em que seja necessário e com a devida oportunidade. 
- Velar para que o processo de editorial seja rigoroso e transparente.

- Cumprir a decisão de aceitação ou rejeição de um artigo para sua publicação.

- Explicitar as condições de acesso à revista e das possibilidades de uso dos diferentes artigos no marco do direito de autor.

- Estabelecer relações cordiais, baseadas no eixo do respeito, com todos os atores envolvidos no processo editorial.

- Resolver de forma oportuna e suficiente as inquietudes que apresentem os atores envolvidos no processo editorial, com respeito ao mesmo.

\section{Para os autores}

- Garantir a originalidade do conteúdo que se apresenta no artigo.

- Garantir que o documento que se submete a consideração para publicação é inédito.

- Respeitar o direito de autor. Não realizar práticas de plágio ou autoplágio.

- Fornecer a informação completa e correta sobre as referências bibliográficas e fontes de informação — de informação, figuras e tabelas — que se utilizam no artigo.

- Obter e fornecer as autorizações que se requeiram das pessoas ou entidades envolvidas na pesquisa, em seus dados, fotografias etc.

- Respeitar a ordem da autoria aceitado pelo grupo de autores.

- Explicitar no artigo as considerações éticas que se tiveram em conta na pesquisa, quando esta assim o requeira.

- Assumir a responsabilidade de suas próprias propostas e da informação que apresenta.

- Realizar, no prazo estabelecido, os ajustes que o texto requeira, dentro do processo editorial.

- Respeitar a confidencialidade sobre pessoas e organizações quando assim se acordou.

- Fornecer os dados requeridos pela revista, através do "Formato de autorização para publicação", com o fim de realizar de forma efetiva o registro de autores em Publindex e restantes bancos de dados nos que forem requerido.

- Estabelecer relações cordiais, baseadas no respeito com todos os agentes envolvidos no processo editorial.

\section{Para os avaliadores}

- Comunicar ao editor quando exista conflito de interesses.

- Cumprir os prazos estabelecidos para o processo de avaliação.

- Realizar uma avaliação séria e fundamentada no rigor científico, na originalidade e na pertinência da informação.

- Seguir o protocolo de avaliação entregado pela revista.

- Realizar de forma respeitosa e construtiva os comentários que surjam a partir da avaliação do artigo.

- Realizar o processo de verificação de ajustes, solicitados na avaliação inicial.

- Manter a confidencialidade do processo de avaliação que realize.

- Fornecer os dados requeridos pela revista, através do "Formato de avaliação de artigos", com o fim de realizar de forma efetiva o registro de avaliadores em Publindex e restantes bancos de dados nos que forem requeridos.

- Estabelecer relações cordiais, baseadas no respeito com todos os agentes envolvidos no processo editorial. 


\section{Para os leitores}

- Fazer uso da informação de acordo com o estabelecido em licença de Creative Commons ReconocimientoNoComercial-SinObraDerivada 4.0 Internacional.

\section{Sobre plágio e autoplágio}

Considera-se plágio a cópia textual ou parcial de ideias alheias que se apresentam como próprias. Portanto, entende-se como apropriação intelectual indevida.

Por isto, cada autor, em seus escritos, deve respeitar o direito que surge sobre ideias, critérios, figuras, tabelas, e em general, todo tipo de obras que se tomem de outros autores, isto é, deve dar-lhes seu respectivo crédito.

Quanto ao autoplágio, trata-se das publicações anteriores elaboradas por autores, que, por sua vez, consideram que podem utilizar informação destes materiais sem indicar que, primeiro, já foram publicados, e segundo, que é de sua autoria. Esta prática, desde qualquer ponto de vista ético, é inapropriada e recusada no âmbito da escrita científica.

Os artigos que incorram em qualquer destas duas situações - plágio ou autoplágio -, não serão considerados, sob nenhuma circunstância, para o processo de publicação na revista. Neste caso se realizará a respectiva notificação de rejeição, fazendo explícito o motivo.

A Revista Escuela de Administración de Negocios utiliza o software Safe Assign para a verificação de plágio e autoplágio em seus artigos.

\section{Code d'éthique et de bonnes conduites éditoriales}

L'Universidad EAN entend stimuler les bonnes pratiques éditoriales de l'institution, des auteurs et des lecteurs. Le code d'éthique garantit par ailleurs le respect du droit d'auteur. En ce sens, les auteurs doivent garantir que les données et les résultats présentés sont originaux, qu'ils peuvent les divulguer, qu'ils n’ont été ni copiés ni manipulés ou déformés.

Conformément aux directives du Comité d'éthique de la publication (COPE), au Code de bonne conduite des pratiques éditoriales (2011), au Code de déontologie des examinateurs (2013) et au Guide des normes internationales des auteurs (2010), la Revue École de Commerce et Gestion présente les lignes directrices suivantes:

\section{Pour l'éditeur}

- Protéger la propriété intellectuelle et le droit d'auteur.

- Maintenir l'indépendance éditoriale.

- Maintenir son engagement en faveur de l'amélioration continue de la revue. 
- Veiller à l'intégrité de la production scientifique publiée dans la revue.

- Publier les corrections, clarifications, retraits et excuses, le cas échéant.

- S’assurer que le processus éditorial est rigoureux et transparent.

- Exécuter la décision d'acceptation ou de rejet d'un article pour publication.

- Expliquer les conditions d'accès à la revue et les possibilités d'utilisation des différents articles dans le cadre du droit d'auteur.

- Établir des relations cordiales, basées sur l’axe du respect, avec tous les acteurs impliqués dans le processus éditorial.

- Résoudre de manière opportune et satisfaisante les préoccupations exprimées par les acteurs impliqués dans le processus éditorial.

\section{Pour les auteurs}

- Garantir l'originalité du contenu présenté dans l'article.

- Garantir que le document soumis à considération n’est pas publié.

- Respecter les droits d’auteur. Ne pas pratiquer le plagiat ou l'auto-plagiat.

- Fournir des informations complètes et correctes sur les références bibliographiques et les sources d'informations (informations, graphiques et tableaux) utilisées dans l'article.

- Obtenir et fournir les autorisations requises des personnes ou entités impliquées dans l'enquête, leurs coordonnées, photographies, etc.

- Respecter l'ordre des auteurs accepté par le groupe d'auteurs.

- Expliciter dans l'article les considérations éthiques prises en compte lors de l'enquête, lorsque cela est nécessaire.

- Assumer la responsabilité des analyses et informations présentées.

- Effectuer, dans le délai imparti, les ajustements requis par le texte, dans le cadre du processus éditorial.

- Respecter le cas échéant la confidentialité des personnes et des organisations.

- Fournir les informations requises par la revue au travers $\mathrm{du}$ «Formulaire d'autorisation de publication» afin de procéder efficacement à l'enregistrement des auteurs dans Publindex et dans d’autres bases de données.

- Établir des relations cordiales, basées sur l'axe du respect, avec tous les acteurs impliqués dans le processus éditorial.

\section{Pour les pairs examinateurs}

- Entrer en contact avec l'éditeur en cas de conflit d'intérêts.

- Respecter les délais fixés pour le processus d'évaluation.

- Réaliser une évaluation sérieuse basée sur la rigueur scientifique, l'originalité et la pertinence de l'information.

- Suivre le protocole d'évaluation fourni par la revue.

- Réaliser de manière respectueuse et constructive les commentaires découlant de l'évaluation de l'article.

- Exécuter le processus de vérification des ajustements demandé dans l'évaluation initiale.

- Maintenir la confidentialité du processus d'évaluation effectué. 
- Fournir les données requises par la revue, via le « format d'évaluation d'article », afin de procéder efficacement à l'enregistrement des évaluateurs dans Publindex et d'autres bases de données.

- Établir des relations cordiales basées sur le respect avec tous les acteurs impliqués dans le processus éditorial.

\section{Pour les lecteurs}

- Utiliser les informations conformément aux dispositions de la licence Creative Commons AttributionNonCommercial-NoDerivada 4.0 International.

\section{À propos du plagiat et de l'autoplaggio}

Le plagiat est la copie textuelle ou partielle d'idées d’autrui présentées comme siennes. Par conséquent, il s'agit d'une appropriation intellectuelle indue.

Chaque auteur doit respecter, dans ses écrits, le droit correspondant aux idées, critères, graphiques, tableaux et à tous types d'œuvres empruntées à d'autres auteurs.

Lautoplaggio correspond aux publications précédentes des auteurs qui considèrent qu'ils peuvent utiliser les informations contenues dans ces documents sans en indiquer leur publication antérieure. Cette pratique est inappropriée et exclue du cadre de la rédaction scientifique.

Les articles se trouvant dans l'une ou l'autre de ces situations - plagiat ou autoplaggio - ne pourront aucunement achever le processus de publication dans la revue. L’avis de rejet sera alors indiqué et le motif explicité.

La Revue Escuela de Administración de Negocios utilise le logiciel Safe Assign pour la vérification du plagiat et de l'autoplaggio des articles. 
